\title{
"Syndrome myxoma": a subset of patients with cardiac myxoma associated with pigmented skin lesions and peripheral and endocrine neoplasms
}

\author{
HUMBERTO J VIDAILLET JR, JAMES B SEWARD, F EARL FYKE III, \\ W P DANIEL SU, A JAMIL TAJIK \\ From the Department of Internal Medicine and the Department of Dermatology, Mayo Clinic and Mayo \\ Foundation, Rochester, Minnesota, USA
}

SUMMARY From January 1954 to December 1985 cardiac myxoma was diagnosed in 75 patients at the Mayo Clinic. The clinical presentation was typical in 70 cases and was referred to as "sporadic myxoma". Forty four other cases of cardiac myxomas (five from the Mayo Clinic) presented with a combination of distinctive clinical features and these cases are described as "syndrome myxoma". The patients with syndrome myxoma were younger (mean age, 25 vs 56 years) and had unusual skin freckling $(68 \%)$, associated benign non-cardiac myxomatous tumours $(57 \%)$, endocrine neoplasms $(30 \%)$, and a high frequency of familial cardiac myxoma $(25 \%$; and familial endocrine tumours $(14 \%)$. The two types of cardiac tumour were different (syndrome $v s$ sporadic): atrial location, $87 \%$ vs $100 \%$; ventricular location, $13 \%$ vs $0 \%$; single tumour, $50 \%$ vs $99 \%$; multiple tumours, $50 \%$ vs $1 \%$; and recurrent tumour, $18 \%$ vs $0 \%$.

It is concluded that patients with syndrome myxoma represent a distinctive subgroup in which there are important clinical, surgical, and genetic implications. More importantly, syndrome myxoma appears to be only one expression of a much larger disease entity.

Although it is rare, cardiac myxoma is the most frequently encountered primary neoplasm of the heart. ${ }^{1}$ Cardiac myxomas are typically sporadic, benign, non-recurring, left atrial tumours. ${ }^{1}$ They are usually attached to the atrial septum, in or about the valve of the fossa ovalis, and are more common in females and in patients aged from 30 to $60 .^{2}$

From a review of experience at the Mayo Clinic and a critical review of published reports we recognised a subset of patients with cardiac myxoma and associated systemic manifestations including pigmented skin lesions and non-cardiac tumours. ${ }^{3}$ These patients have distinctive clinical features that separate them from the larger group of patients with the more common sporadic myxoma. ${ }^{2}$ We call the condition in this subset of patients "syndrome myxoma".

Requests for reprints to Dr James B Seward, Mayo Clinic, 200 First Street SW, Rochester, MN 55905, USA.

Accepted for publication 13 October 1986
We have compared sporadic myxoma with syndrome myxoma and we summarise the specific findings that allow clinical distinction between the two. The most important distinction is that syndrome myxoma appears to be a multisystem disease.

\section{Patients and methods}

From 1954 to 1985,75 patients with cardiac myxoma were seen at the Mayo Clinic. Seventy of them had the sporadic type of cardiac myxoma. Five $(7 \%$ ) patients have subsequently been recognised as having an atypical presentation and these were the original cases that prompted the use of the term syndrome myxoma. We defined syndrome myxoma as cardiac myxoma with one or more of the following features: cutaneous lentiginosis or unusual hyperpigmented skin lesions (that is, unusual or excessive freckling), non-cardiac myxoid tumours or neurofibromas, or a rare endocrine neoplasm. When we used these three criteria to review published reports we found 39 additional cases of syndrome 
Table 1 Details of 44 patients with syndrome myxoma

\begin{tabular}{|c|c|c|c|c|c|c|c|c|c|}
\hline $\begin{array}{l}\text { Ciase } \\
\text { No }\end{array}$ & Reference & $\begin{array}{l}A g e \\
\text { '.tri }\end{array}$ & Sex & Cardiac myxoma & $\begin{array}{l}\text { Pigmented } \\
\text { macules }\end{array}$ & $\begin{array}{l}\text { Non-cardiac } \\
\text { myxoma }\end{array}$ & Other & $\begin{array}{l}\text { Familial } \\
\text { feature }\end{array}$ & Clinical features \\
\hline 1 & 4 & 16 & $\mathbf{M}$ & LA and I.V $S$ & $t$ & - & - & - & Blue naevi (multiple) $)^{\omega^{\circ}}$ \\
\hline 2 & 5 & 10 & M & Biatrial $(S)$ & $t$ & Sk (NF) & $\mathrm{AH}$ & & Blue naevi \\
\hline 3 & 6 & 29 & $M$ & $L A$ and $R V S$ & - & Sk & - & - & $\begin{array}{l}\text { Hürthle cell thyroid } \overline{\bar{\sigma}} \\
\text { adenoma }\end{array}$ \\
\hline 4 & 7 & 20 & $\mathbf{F}$ & 4 in $\mathrm{RA}(S)$ & - & $\mathrm{Sk}, \mathrm{Br}, \mathrm{U}$ & AH, pheo & + & Sister of case 5 \\
\hline 5 & 7 & $?$ & $\mathbf{F}$ & Site unknown & + & $\mathrm{Sk}, \mathrm{Br}$ & $\mathrm{AH}$ & + & 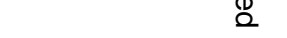 \\
\hline 6 & 8 & 16 & $\mathbf{M}$ & RV & - & Sk & I.CCSC & - & עు \\
\hline 7 & 9 & 12 & $\mathbf{F}$ & RA & - & $\mathrm{Br}$ & $\mathrm{AH}$ & + & Mother had I.A myxot \\
\hline 8 & 10 & 29 & F & Biatrial $(\mathbf{S})$ & $t$ & - & - & - & $\overrightarrow{0}$ \\
\hline 9 & 11 & 22 & $\mathbf{F}$ & Biatrial (S) & $t$ & - & - & - & \\
\hline 10 & 12 & $\begin{array}{l}16 \\
18 \\
20\end{array}$ & $\mathbf{F}$ & $\begin{array}{l}\text { I.A } \\
\text { I.A }(\mathbf{R}) \text { (multiple) } \\
\text { RA and I.A }(\mathbf{R}) \\
\quad(\text { multiple) } \\
\text { RA }(\mathbf{R})\end{array}$ & $t$ & $\mathrm{Sk}, \mathrm{Br}$ & - & + & $\begin{array}{l}\text { Four myxoma operatiens } \\
\text { (sece fig 3) }\end{array}$ \\
\hline 11 & 12 & 56 & $\mathbf{M}$ & I.A & $t$ & Sk & - & + & $\begin{array}{c}\text { Father of case } 10 \\
\text { (see fig 3) }\end{array}$ \\
\hline 12 & 13 & 14 & F & Biatrial $(S)$ & + & $\overline{c i}$ & - & - & N \\
\hline 13 & 14 & 45 & F & $\underset{(S)}{R A}, I, A, R V, I, V$ & - & Sk & $\mathrm{AH}$ & - & $\begin{array}{l} \pm \\
0\end{array}$ \\
\hline 14 & 15 & $\begin{array}{l}46 \\
46 \\
52\end{array}$ & $\mathbf{M}$ & $\begin{array}{l}\text { I.A (2 stalks) } \\
4 \text { LA } \\
\text { 6 I.A } \\
\text { RA }\end{array}$ & - & Sk & - & + & 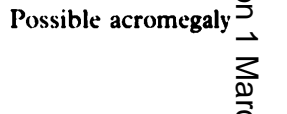 \\
\hline 15 & 16 & 23 & M & RV & - & Sk & LCC.SC: & + & $\begin{array}{l}\text { Identical twin with } \\
\text { myxoma }\end{array}$ \\
\hline 16 & 17 & $?$ & F: & Site unknown & - & - & $\mathrm{AH}$ & & 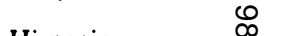 \\
\hline $\begin{array}{l}17 \\
18\end{array}$ & 18 & 12 & F & 2 I.A $(S)$ & + & $\bar{c}$ & - & - & Hispanic \\
\hline 18 & 19 & 25 & $\mathbf{F}$ & RA & & $\mathrm{Sk}, \mathrm{Br}$ & - & + & \\
\hline 19 & 20 & 24 & $\mathbf{F}$ & I.A, I.V (S) & + & $\mathrm{Sk}, \mathrm{Br}$ & - & + & $\begin{array}{l}\text { Brother with acromegidy } \\
\text { cardiac myxoma, } \\
\text { lentigines }\end{array}$ \\
\hline 20 & 21 & 18 & $M$ & I.A & - & Sk & - & - & 3 myxoma operation \\
\hline 21 & 22 & 19 & $M$ & RA & + & - & - & - & 응 \\
\hline $\begin{array}{l}22 \\
23\end{array}$ & 23 & 14 & $M$ & I.A & + & 一 & $\bar{v}$ & -- & @( \\
\hline 23 & 24 & 26 & $\mathrm{M}$ & RV & $t$ & - & Test. tumour & - & \\
\hline 24 & 25 & 16 & $\mathrm{M}$ & I.V & t & - & AH, LCCSC: & + & Brother of case 25 으 \\
\hline 25 & 25 & 10 & $\mathbf{M}$ & I.A & t & 一 & AH, LCCSC & + & Brother of case 24 \\
\hline 26 & 26 & $?$ & $\mathrm{~F}$ & Site unknown & & & Acromegaly & - & 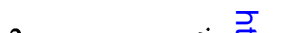 \\
\hline 27 & 27 & 18 & $\mathbf{M}$ & L.A & + & Palate NF & - & & 2 myxoma operation \\
\hline 28 & 28 & 10 & $\mathrm{~F}$ & RA & $t$ & Sk, Br, vulva & - & - & Blue naevi \\
\hline 29 & 28 & $?$ & F & Sitc unknown & t & - & - & + & D \\
\hline 30 & 28 & $?$ & $\mathbf{M}$ & Site unknown & t & - & - & + & 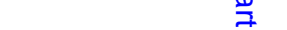 \\
\hline 31 & 28 & $?$ & F & Site unknown & + & $\bar{v}$ & - & + & $\ddot{\sigma}$ \\
\hline 32 & $\begin{array}{l}29 \\
30\end{array}$ & $\begin{array}{l}33 \\
39\end{array}$ & $\mathbf{F}$ & $\begin{array}{l}\text { L.A } \\
\text { I.A }(\mathbf{R})\end{array}$ & - & $\mathrm{Br}, \mathrm{FA}$ & - & - & 2 myxoma operation \\
\hline 33 & 29 & 37 & $\mathbf{F}$ & I.A & - & $\mathrm{Br}, \mathrm{FA}$ & - & - & 윽 \\
\hline 34 & 31 & 36 & $\mathbf{F}$ & LA & t & $\mathrm{Br}, \mathrm{FA}, \mathrm{Sk}$ & $\mathrm{AH}$ & + & Brother with LA muxoma \\
\hline 35 & 32 & 25 & $\mathbf{F}$ & RA, 2 I.A (S) & - & Palate NF & - & $t$ & $\begin{array}{l}\text { Hispanic, sister withd्d } \\
\text { myxoma }\end{array}$ \\
\hline $\begin{array}{l}36 \\
37\end{array}$ & 33 & 30 & $\mathbf{F}$ & RV & + & $\mathrm{Br}$, vulva, NF & - & -- & $\frac{D}{0}$ \\
\hline $\begin{array}{l}37 \\
38\end{array}$ & 34 & 15 & $\mathbf{F}$ & RA, 2 I.A (S) & $t$ & Sk & - & - & \\
\hline $\begin{array}{l}38 \\
39\end{array}$ & PC, & 12 & $\mathbf{F}$ & Biatrial (S) & + & - & - & - & Hispanic \\
\hline 39 & PC: & 37 & $\mathbf{F}$ & I.V & + & $\overline{0}$ & - & - & Multiple naevi \\
\hline 40 & Mayo & $\begin{array}{l}17 \\
19\end{array}$ & $\mathrm{~F}$ & $\begin{array}{l}\text { Biatrial (S) } \\
\text { RA (R) }\end{array}$ & + & $\begin{array}{l}\text { Sk } \\
\text { Sk }\end{array}$ & - & - & 2 myxoma operations \\
\hline 41 & Mayo & $\begin{array}{r}32 \\
35 \\
45\end{array}$ & $\mathbf{F}$ & $\begin{array}{l}\text { 3 RA (S) } \\
\text { 4 I.A (S) } \\
\text { LA }(\mathbf{R})\end{array}$ & $t$ & $\mathrm{Br}, \mathrm{FA}$ & - & - & $\begin{array}{l}3 \text { myxoma operations } \\
\text { (see fig 4) }\end{array}$ \\
\hline 42 & Mayo & 33 & $\mathbf{F}$ & I.A & + & $\bar{x}$ & - & & $\mathscr{O}$ \\
\hline 43 & Mayo & 52 & $\mathrm{M}$ & I.A & $t$ & Vocal cord & - & - & С \\
\hline 44 & Mayo & $\begin{array}{l}33 \\
43\end{array}$ & $\mathbf{F}$ & $\begin{array}{l}\text { RA } \\
\text { 2 RA, I.A (R) (S) }\end{array}$ & + & Sk & - & -- & 2 myxoma operationș \\
\hline
\end{tabular}

AH, adrenal hyperplasia; Br, breast; FA, fibroadenoma; LA, left atrium; LCCSC, large cell calcifying Sertoli cell testicular tumour; LV, left vePrich $\mathrm{NF}$, neurofibroma; PC, personal communication; pheo, pheochromocytoma; R, recurrence; RA, right atrium; RV, right ventricle; S, synchronous; Sipsti Test., testicular; U, uterus; V, ventricle; ?, not known.

myxoma. Each example was originally reported as an isolated case. We compared the 44 cases of syndrome myxoma with the 70 cases of sporadic cardiac myxoma at the Mayo Clinic.

\section{Results}

SYNDROME MYXOMA PATIENTS

Table 1 shows data on the 44 patients with syndrome 

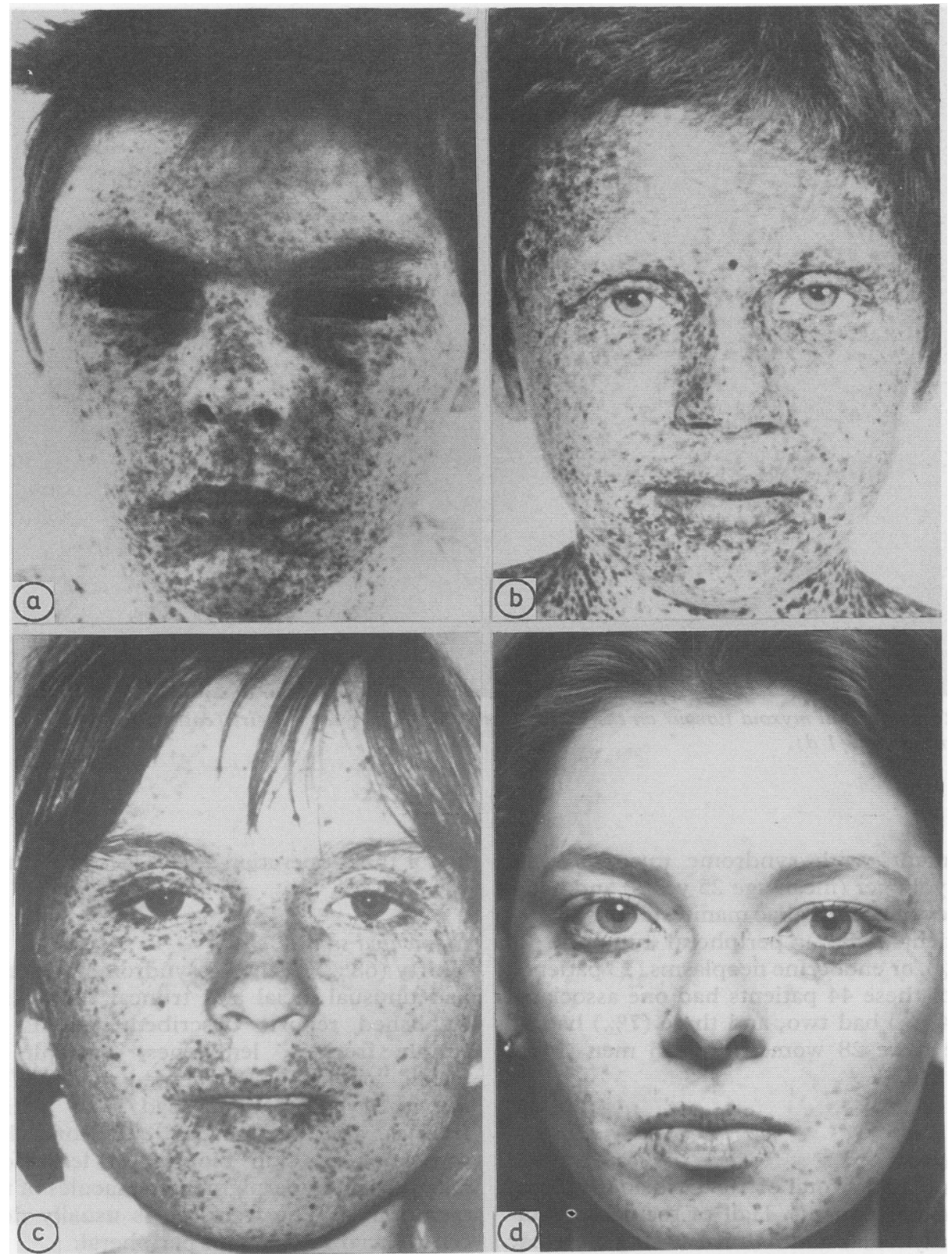

Fig 1 Unusual facial freckling in four patients with atrial myxoma. (a) Eighteen year old man (case 27) with extensive freckling, palatal myxoid neurofibroma, and reddish hair. (From Rees et al. ${ }^{27}$ By permission of the British Heart fournal.) (b) Ten year old boy (case 4) with biatrial myxoma, freckling, skin myxoid neurofibromas, blue naevi, and rust red hair. (From Atherton et al. ${ }^{5}$ By permission of the British Association of Dermatologists.) (c) Fourteen year old boy (case 23) with left atrial myxoma, lentigines, and red hair. (From Peterson and Serrill ${ }^{23}$; by permission of the American Academy of Dermatology, Inc.) (d) Seventeen year old girl (case 40) with biatrial myxoma; right atrial myxoma recurred at age 19. There were extensive freckling and skin myxomas. 


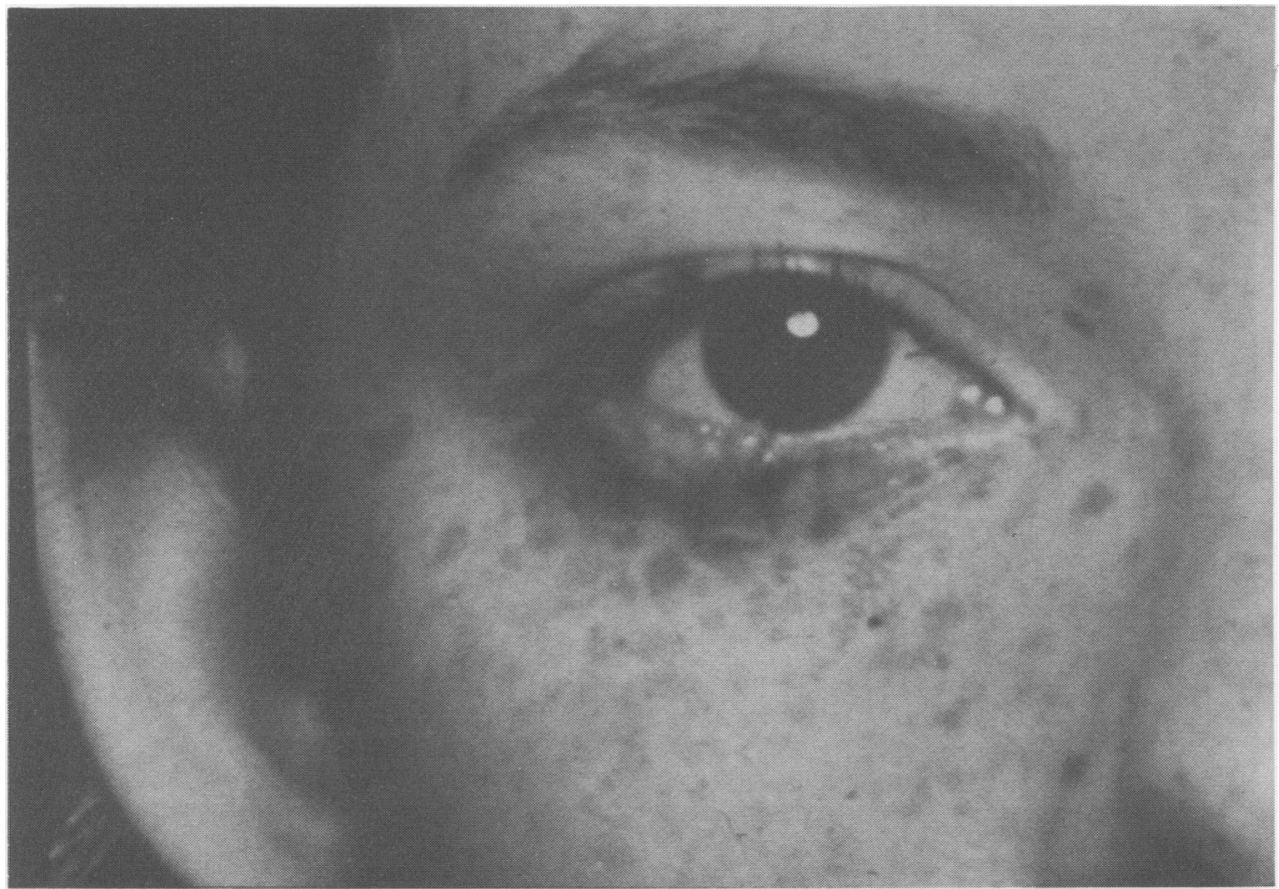

Fig 2 Peripheral myxoid tumour on the lower right eyelid of 17 year old girl (case 40) (same patient as in fig $1 d$ ).

myxoma. Patients with syndrome myxoma were significantly younger (mean age 25 years) and had a high frequency of non-cardiac manifestations: freckling ( 30 patients, $68 \%$ ), peripheral tumours ( 25 patients, $57 \%$ ), or endocrine neoplasms ( 13 patients, $30 \%$ ). Half of these 44 patients had one associated feature, $19(43 \%)$ had two, and three $(7 \%)$ had all three. There were 28 women and 16 men (ratio, $1 \cdot 8: 1)$.

\section{Cardiac myxoma}

The 44 patients had a total of 103 cardiac myxomas (2.3 myxomas per patient). Half of them had multiple cardiac myxomas and half had a single cardiac myxoma. In patients with single tumours, $41 \%$ were in the left atrium, $24 \%$ were in the right atrium, and $35 \%$ were in the ventricles. Twelve $(27 \%)$ of the 44 patients had at least one ventricular myxoma.

Fifty two $(50 \%)$ of the 103 tumours were in the left atrium, $32(31 \%)$ were in the right atrium (10 were synchronous biatrial), $13(13 \%)$ were ventricular (7 right and 6 left), and in six the affected chamber was unknown. Eight $(18 \%)$ of the 44 patients had at least one recurrence of a cardiac myxoma and three had a third operation for recurrence (cases 10, 20, $\frac{\overrightarrow{\vec{O}}}{3}$ 41).

\section{Pigmented skin lesions}

Thirty $(68 \%)$ of the 44 syndrome myxoma patientsक had unusual facial and truncal "freckling" (fig 1) Published reports described patients as havingo simple freckles, lentigenes, multiple superficial. naevi, "cutaneous pigmented macules," and blueo naevi. Several patients had both lentigenes and freckles. Each type of cutaneous lesion was? confirmed by skin biopsy. At least four of the patients had hyperpigmented macules of the mucous membranes. The freckling is usually described as centrofacial rather than peripheral.

\section{Peripheral tumours}

Peripheral myxoid tumours (fig 2) or neurofibromas were present in $25(57 \%)$ of the 44 patients; the siteso included the breasts, face, extremities, torso, vulva uterus, buttocks, and vocal cords. Two patients? (cases 27 and 35) had neurofibromas of the palate $\overparen{T}$ Histologically these tumours were myxomas $\frac{\vec{D}}{\mathrm{D}}$ myxoid fibroadenomas, myxoid neurofibromas? neurofibromas, and myxoid leiomyomas. Severa 

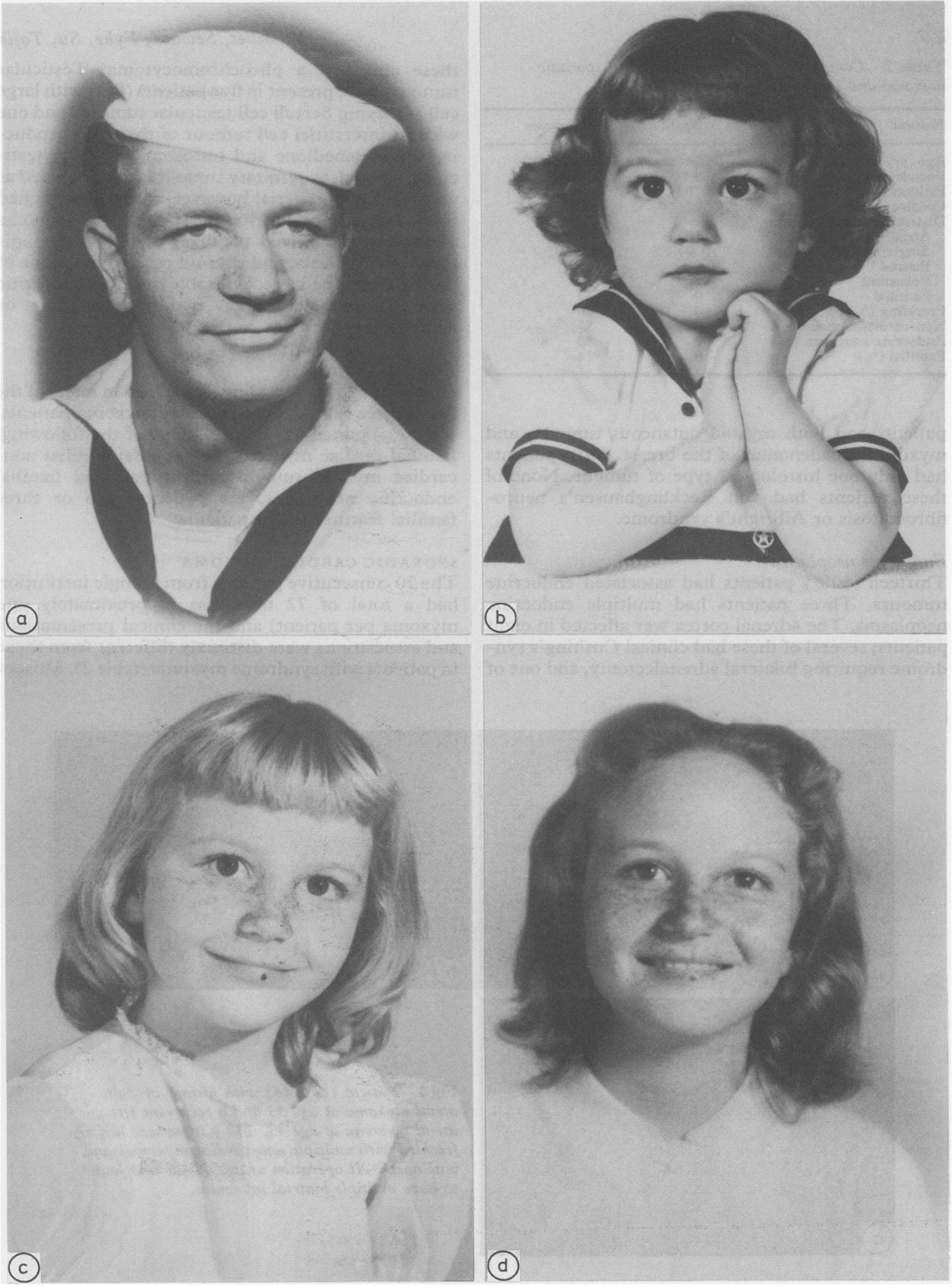

Fig 3 (a) The father is pictured in his twenties; diffuse lentiginoses were present. He died at age 56 from a left atrial myxoma. His daughter $(b, c, d)$ pictured at ages 2,7 , and 13 years, had diffuse lentiginoses that were apparent at a very early age and became more apparent with age. She died aged 21 after four operations for cardiac myxomas. 
Table 2 Comparison of clinical features of sporadic myxoma and syndrome myxoma

\begin{tabular}{lll}
\hline Feature & Sporadic & Syndrome \\
\hline Age (yr) (range) & $56(39-82)$ & $25(10-56)$ \\
Female/male ratio & $27: 1$ & $1 \cdot 8: 1$ \\
Patients (No) & 70 & 44 \\
Cardiac myxomas (No) & 72 & 103 \\
Distributions of myxomas (\%): & & \\
Atrial/ventricular & $100 / 0$ & $87 / 13$ \\
Single/multiple & $99 / 1$ & $50 / 50$ \\
Biatrial & 0 & 23 \\
Recurrent & 0 & 18 \\
Familial & 0 & 27 \\
Freckling (\%) & 0 & 68 \\
Non-cardiac tumours (\%) & 0 & 57 \\
Endocrine neoplasm (\%) & 0 & 30 \\
Familial (\%) & 0 & 14 \\
\hline
\end{tabular}

patients had both myxoid cutaneous tumours and myxoid fibroadenomas of the breast. Most patients had only one histological type of tumour. None of these patients had von Recklinghausen's neurofibromatosis or Albright's syndrome.

\section{Endocrine neoplasms}

Thirteen $(30 \%)$ patients had associated endocrine tumours. Three patients had multiple endocrine neoplasms. The adrenal cortex was affected in eight patients; several of these had clinical Cushing's syndrome requiring bilateral adrenalectomy, and one of these also had a pheochromocytoma. Testicularo tumours were present in five patients (four with large ${ }_{C}^{-}$ cell calcifying Sertoli cell testicular tumours and one with an interstitial cell tumour of the testis producing androstanedione and testosterone). Only testi-o cular, adrenal, or pituitary tumours were regarded as 흐 valid for entry criteria; however, many patients had $\overline{\bar{s}}$. thyroid neoplasms, including Hürthle cell adenoma of the thyroid, mixed papillary and follicular epi-n thelial hyperplasia, and thyroid carcinoma. None of these patients had a recognisable multiple endocrine. adenomatosis syndrome, neurofibromatosis, or $\vec{\omega}$ Albright's syndrome.

\section{Familial features}

In addition to the freckling (fig 3 ) seen in many of the first degree relatives of syndrome myxoma patients, $15(34 \%)$ patients had at least one of the following: familial cardiac myxoma, 11 patients; familial non-윽 cardiac myxoid tumours, eight patients; familial endocrine neoplasms, six patients; two or threez familial features, eight patients.

\section{SPORADIC CARDIAC MYXOMA}

The 70 consecutive patients from a single institution had a total of 72 myxomas (approximately one myxoma per patient) and the clinical presentationso and associations were distinctly different from those in patients with syndrome myxoma (table 2 ). Most of:

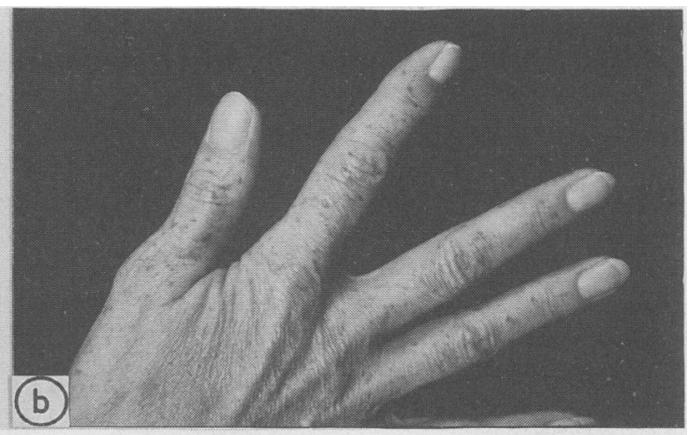

Fig 4 Patient (case 44) with history of right atrial myxoma at age 33 and a recurrent left atrial myxoma at age 43. The patient was heavily freckled with multiple non-cardiac myxomas and blue naevi. At operation at age 43 she was found to have multiple biatrial myxomas. 
these patients have been reported elsewhere. ${ }^{35-37}$ There were no bilateral or ventricular myxomas. There were no recurrences and no associated familial features. None of the patients with sporadic myxoma had unusual freckling or lentiginosis, peripheral myxoid tumours or neurofibromas, or adrenocortical or testicular tumours. The group comprised 51 women and 19 men (ratio, 2.7:1) with a mean age of 56 years.

\section{Discussion}

In 1960, Frankenfeld et al described a 22 year old white woman with "many dark brown to black freckles on the skin" and synchronous biatrial cardiac myxomas. ${ }^{11}$ Although these investigators recognised the rarity of biatrial cardiac tumours, they did not appreciate the significance of the cutaneous hyperpigmentation. In 1973, Rees et al reported, in the British Heart fournal, the association of cutaneous lentiginosis and a left atrial myxoma in an 18 year old man (fig 1). ${ }^{27}$ In 1980, Atherton et al described additional features-namely, peripheral tumours and blue naevi-in a 10 year old boy with a synchronous biatrial myxoma (fig 1). ${ }^{5}$ In 1982, SchweizerCagianut et al, unaware of the reports by Rees et al and Atherton et al, described a single family with cardiac myxomas and familial endocrine neoplasms. ${ }^{31}$ In 1984, Rhodes et al described another case and raised the question of the possible association of endocrine neoplasms and cardiac myxoma. ${ }^{28}$ There had been earlier reports of cardiac myxoma and an association with fibroadenoma of the breast. ${ }^{29}$ In 1984, we reported our observations on patients with cardiac myxoma and the belief that a subset of these patients represented a unique subgroup. ${ }^{3}$ (In April 1984 this paper was the winner of the Associate Clinical Paper Competition at the meeting of the American College of Physicians in Atlanta.) Other investigators at the Mayo Clinic subsequently reported a review of the features of patients with a complex of myxomas, spotty pigmentation, and endocrine overactivity that included atrial myxoma. ${ }^{26}$

Previous descriptions of syndrome myxoma patients have usually appeared as isolated case reports. To date we have recognised five patients who originally presented at the Mayo Clinic and 39 gleaned from international reports. All 44 had cardiac myxomas; and this report is the first review to concentrate on syndrome myxoma patients with a cardiac myxoma.

A significant feature of this unique subgroup is young age (mean age, 25 vs 56 years), and the condition is typically associated with cutaneous lentiginosis, blue naevi, peripheral tumours, and endocrine neoplasms. It is not clear whether these patients have true freckles or lentiginosis; however, we favour the latter interpretation.

Approximately $50 \%$ of the patients with syndrome myxoma have multiple cardiac myxomas with a high frequency of biatrial, ventricular, and recurrent myxomas. In our review of published reports we found patient subgroups with cardiac myxoma in which syndrome features were common (syndrome/total): synchronous biatrial myxomas, $13 / 32(41 \%)^{38}$; ventricular myxomas, $12 / 77(16 \%)$; age <18 years, $15 / 66(23 \%)$; recurrent cardiac myxomas, $7 / 33(21 \%)^{39}$; multiple cardiac myxomas, $17 / 54(31 \%)^{39}$; and familial cardiac myxomas, $12 / 30$ $(40 \%){ }^{39}$

The familial manifestations of the syndrome myxoma patients are particularly interesting. Of 12 reported families with familial cardiac myxoma, ${ }^{79121625313240-44}$ seven $(58 \%)$ had at least one family member with syndrome myxoma. For this presentation, we excluded relatives of syndrome patients with cardiac myxoma who failed to meet any of the three additional entry criteiia (relatives in cases $9,16,31$, and 32 ). It is strongly suggested, however, that these relatives are likely to have the syndrome.

This syndrome is probably a "genetic" disorder in the mendelian sense, but much more extensive family studies will be needed before a specific pattern of inheritance can be identified. ${ }^{45}$ Individual cases of familial cardiac myxoma ${ }^{45}$ may resemble cases of syndrome myxoma: patients with familial cardiac myxoma are younger and have a higher frequency of multiple, biatrial, and ventricular myxomas. For the present, however, the prudent physician should be aware of the possibility of familial occurrence and advise the first degree relatives (parents, siblings, and children) of patients with syndrome myxoma to be examined.

Theories about the pathogenesis of this syndrome remain speculative. Although we believe that syndrome myxoma is a separate entity, many other diseases can have some of the same characteristic features. Other cardiac syndromes with lentiginosis or freckling include electrocardiographic abnormalities ${ }^{46}$ valvar heart disease,${ }^{47}$ hypertrophic cardiomyopathy, ${ }^{48}$ and the LEOPARD syndrome ${ }^{49}(\mathrm{~L}=$ lentigenes, $\mathrm{E}=$ electrocardiographic conduction defect, $\mathrm{O}=$ ocular hypertension, $\mathrm{P}=$ pulmonary valve stenosis, $\mathbf{A}=$ abnormalities of genitals, $\mathbf{R}=$ retardation of growth, and $D=$ deafness). Other entities such as von Recklinghausen's neurofibromatosis, ${ }^{50}$ centrofacial lentiginosis, ${ }^{51}$ multiple endocrine neoplasia type $3,^{52}$ LEOPARD syndrome, ${ }^{53}$ and Peutz-Jeghers ${ }^{54}$ syndrome are associated with diffuse lentiginosis and endocrine 
abnormalities and have an autosomal dominant mode of inheritance. Albright's fibrous dysplasia ${ }^{55}$ and neurofibromatosis ${ }^{56}$ are associated with hyperpigmented skin lesions, endocrine abnormalities, and soft tissue myxomas. Unlike most of these similar conditions, which are the result of a mutation in the embryonic neural crest, ${ }^{5657}$ myxomas are believed to be of mysenchymal origin. A recent report, however, suggests the possibility of maldevelopment of the neural crest in cardiac myxoma. ${ }^{58}$

We have avoided the use of mnemonic acronyms such as $\operatorname{NAME}^{5}$ ( $N=$ naevi, $A=$ atrial myxoma, $M$ $=$ mucocutaneous myxomas, $\mathbf{E}=$ ephelides) or $\mathrm{LAMB}^{\mathbf{2 8}}(\mathrm{L}=$ lentigines, $\mathrm{A}=$ atrial myxoma, $\mathrm{M}=$ mucocutaneous myxomas, $B=$ blue naevi) to describe the features of syndrome myxoma. Such acronyms describe only some of the manifestations of the syndrome, which appears to be a multisystem condition that may be associated with cardiac myxoma. We therefore believe there is no suitable acronym.

In summary, syndrome myxoma should be suspected in any patient under age $\mathbf{4 0}$ years with a cardiac myxoma at a site other than the left atrium. Such patients should be assessed preoperatively for important associations including adrenal integrity, and the surgeon should be made aware of the need for thorough inspection of the heart for multiple subclinical myxomas. Any patient who has familial, recurrent, ventricular, or multiple cardiac myxomas and is unusually freckled or has peripheral noncardiac myxomas or a rare endocrine neoplasm should be followed because syndrome myxoma often recurs. If syndrome myxoma is recognised in an individual, all the first degree relatives should undergo formal evaluation. Cardiac myxoma appears to be only one of the many manifestations of syndrome myxoma.

We thank Dr James E Vanek, Dr Leonard Zon, Dr Patrick M McCarthy, Dr Robert E Whalen, Dr Robert P Bolande, Dr Ralph G Koon, and Mr James W Nesmith, for personal communication of information.

\section{References}

1 McAllister HA Jr, Fenoglio JJ Jr. Tumours of the cardiovascular system. In: Atlas of tumour pathology, Fascicle 15. Washington DC: Armed Forces Institute of Pathology, 1978:1-20.

2 Braunwald E: Heart disease: a textbook of cardiovascular medicine. 2nd ed. Philadelphia: WB Saunders, 1984:1457-69.

3 Vidaillet HJ Jr, Seward JB, Fyke E III, Tajik AJ. NAME syndrome (nevi, atrial myxoma, myxoid

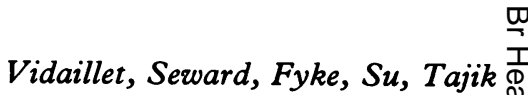
neurofibroma, ephelides): a new and unrecognized subset of patients with cardiac myxoma. Minn Med. 1984;67:695-6.

4 Abramowitz R, Majdan JF, Plzak LF, Berger BC. Two-dimensional echocardiographic diagnosis of separate myxomas of both the left atrium and left ventricle. Am $\mathcal{F}$ Cardiol 1984;53:379-80.

5 Atherton DJ, Pitcher DW, Wells RS, MacDonald DM. A syndrome of various cutaneous pigmented lesions, myxoid neurofibromata and atrial myxoma: the NAME syndrome. Br f Dermatol 1980;103:421-9.

6 Balk AHM, Wagenaar SS, Bruschke AVG. Bilateral cardiac myxomas and peripheral myxomas in a patient with recent myocardial infarction. $A m \mathcal{F}$ Cardiol 1979;44:767-70.

7 Barlow JF, Abu-Gazeleh S, Tam GE, et al. Myxoid O tumor of the uterus and right atrial myxomas. $S D \mathcal{F}$ Med July 1983;36:9-13.

8 Chandraratna PAN, San Pedro S, Elkins RC, Gran-

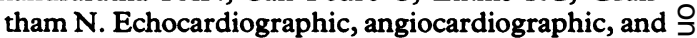
surgical correlations in right ventricular myxoma simulating valvar pulmonic stenosis. Circulation $\bar{z}$ 1977;55:619-22.

9 Crawford FA Jr, Selby JH Jr, Watson D, Joransen J. Unusual aspects of atrial myxoma. Ann Surg 1978;188:240-4.

10 Dashkoff N, Boersma RB, Nanda NC, Gramiak R, Andersen MN, Subramanian S. Bilateral atrial myxomas: echocardiographic considerations. $\mathrm{Am} \mathcal{f}$ Med 1978;65:361-6.

11 Frankenfeld RH, Waters CH, Steiner RC. Bilateral myxomas of the heart. Ann Intern Med 1960; 53:827-38.

12 Grauer K, Grauer MC. Familial atrial myxoma with bilateral recurrence. Heart Lung 1983;12:600-2.

13 Hanly J, Shaw K, De Buitleir M, Maurer B, Fitzgerald $\mathrm{MX}$. Bi-atrial myxomas presenting as recurrent pulmonary emboli in a girl. Postgrad Med $\mathcal{f}$ 1984; 60:147-50.

14 Honey M, Axelrad MA. Intracardiac endodermal heterotopia. Br Heart $\mathcal{F}$ 1962;24:667-70.

15 Jugdutt BI, Rossall RE, Sterns LP. An unusual case of recurrent left atrial myxoma. Can Med Assoc $\mathcal{f} 0$ 1975;112:1099-100.

16 Laboux L, Mussini-Montpellier J, Michaud JL, Gail- $ᄋ$ lard F, Pelleray C, Cornet E. Myxoma du ventricule droit chez des jumeaux monozygotes: ablation chirurgicale. Arch Mal Coeur 1978;71:953-9.

17 Levin ME. The development of bilateral adenomatous $\tilde{O}$ adrenal hyperplasia in a case of Cushing's syndrome of eighteen years' duration. Am $\mathcal{F}$ Med 1966; 40:318-24.

18 Lortscher RH, Toews WH, Nora JJ, Wolfe RR, Q Spangler RD. Left atrial myxoma presenting as rheu- $O$ matic fever. Chest 1974;66:302-3.

19 Lund HZ. Tumors of the skin. In: Atlas of tumor $\stackrel{5}{?}$ pathology, Fascicle 2. Washington DC: Armed Forces Institute of Pathology, 1957:276.

20 Morgan DL, Palazola J, Reed W, Bell HH, Kindred

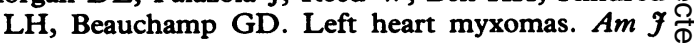
Cardiol 1977;40:611-4.

21 O'Neill MB Jr, Grehl TM, Hurley EJ. Cardiac myxo- 
mas: a clinical diagnostic challenge. Am $f$ Surg 1979;138:68-74.

22 Pavie A, Escande G, Cham B, et al. Les myxomes de l'oreillette droite: à propos de 3 observations; revue de la littérature. Arch Mal Coeur 1981;74:265-72.

23 Peterson LL, Serrill WS. Lentiginosis associated with a left atrial myxoma. $\mathcal{f} A m$ Acad Dermatol 1984;10:337-40.

24 Ports TA, Schiller NB, Strunk BL. Echocardiography of right ventricular tumours. Circulation 1977; 56:439-47.

25 Proppe KH, Scully RE. Large-cell calcifying Sertoli cell tumor of the testis. Am $\mathcal{f}$ Clin Pathol 1980;74:607-19.

26 Carney JA, Gordon H, Carpenter PC, Shenoy BV, Go VLW. The complex of myxomas, spotty pigmentation, and endocrine overactivity. Medicine (Baltimore) 1985;64:270-83.

27 Rees JR, Ross FGM, Keen G. Lentiginosis and left atrial myxoma. Br Heart f 1973;35:874-6.

28 Rhodes AR, Silverman RA, Harrist TJ, Perez-Atayde AR. Mucocutaneous lentigines, cardiomucocutaneous myxomas, and multiple blue nevi: the "LAMB" syndrome. f Am Acad Dermatol 1984; 10:72-82.

29 Roper CL, Camp FA, Kempson RL. Atrial myxoma associated with fibroadenomas of the breast. Mo Med 1965;62:113-6.

30 Bahl OP, Oliver GC, Ferguson TB, Schad N, Parker BM. Recurrent left atrial myxoma: report of a case. Circulation 1969;40:673-6.

31 Schweizer-Cagianut M, Salomon F, Hedinger CE. Primary adrenocortical nodular dysplasia with Cushing's syndrome and cardiac myxomas: a peculiar familial disease. Virchows Arch [A] 1982;397:183-92

32 Tway KP, Shah AA, Rahimtoola SH. Multiple biatrial myxomas demonstrated by two-dimensional echocardiography. Am $\mathcal{F}$ Med 1981;71:896-9.

33 Zager J, Smith JO, Goldstein S, Franch RH. Tricuspid and pulmonary valve obstruction relieved by removal of a myxoma of the right ventricle. $\mathrm{Am} \mathrm{f}$ Cardiol 1973;32:101-4.

34 Zajtchuk R, Fitterer JD, Strevey TE, Nelson WP. Bilateral atrial myxomas: preoperative diagnosis and successful removal. If Thorac Cardiovasc Surg 1975;69:291-4.

35 Miller JI, Mankin HT, Broadbent JC, Giuliani ER, Danielson GK. Primary cardiac tumors: surgical considerations and results of operation. Circulation 1972;45 (suppl 1):134-8.

36 St John Sutton MG, Mercier L-A, Giuliani ER, Lie JT. Atrial myxomas: a review of clinical experience in 40 patients. Mayo Clin Proc 1980;55:371-6.

37 Fyke FE III, Seward JB, Edwards WD, et al. Primary cardiac tumours: experience with 30 consecutive patients since the introduction of two-dimensional echocardiography. $\mathcal{F} \mathrm{Am}$ Coll Cardiol 1985; 5:1465-73.

38 Vidaillet HJ Jr, Seward JB, Fyke FE III, Tajik AJ. Bilateral myxomas: much more than cardiac myxomas in either side of the atrial septum: a "syndrome" myxoma? [Abstract]. Chest 1985;88:10S.

39 McCarthy PM, Piehler JM, Schaff HV, et al. The significance of multiple, recurrent, and "complex" cardiac myxomas. $\mathcal{f}$ Thorac Cardiovasc Surg 1986;91:389-6.

40 Kleid JJ, Klugman J, Haas J, Battock D. Familial atrial myxoma. Am $\mathcal{f}$ Cardiol 1973;32:361-4.

41 Liebler GA, Magovern GJ, Park SB, Cushing WJ, Begg FR, Joyner CR. Familial myxomas in four siblings. F Thorac Cardiovasc Surg 1976;71:605-8.

42 Powers JC, Falkoff M, Heinle RA, et al. Familial cardiac myxoma: emphasis on unusual clinical manifestations. $\mathcal{F}$ Thorac Cardiovasc Surg 1979;77:782-8.

43 Siltanen P, Tuuteri L, Norio R, Tala P, Ahrenberg P, Halonen PI. Atrial myxoma in a family. Am $\mathcal{F}$ Cardiol 1976;38:252-6.

44 Farah MG. Familial atrial myxoma. Ann Intern Med 1975;83:358-60.

45 Carney JA. Differences between nonfamilial and familial cardiac myxoma. Am f Surg Pathol 1985;9:53-5.

46 Walther RJ, Polansky BJ, Grots IA. Electrocardiographic abnormalities in a family with generalized lentigo. $N$ Engl f Med 1966;275:1220-5.

47 Forney WR, Robinson SJ, Pascoe DJ. Congenital heart disease, deafness, and skeletal malformations: a new syndrome? f Pediatr 1966;68:14-26.

48 St John Sutton MG, Tajik AJ, Giuliani ER, Gordon H, Su WPD. Hypertrophic obstructive cardiomyopathy and lentiginosis: a little known neural ectodermal syndrome. Am F Cardiol 1981;47:214-7.

49 Gorlin RJ, Anderson RC, Blaw M. Multiple lentigenes syndrome. Am $\mathcal{F}$ Dis Child 1969;117:652-62.

50 Fienman NL, Yakovac WC. Neurofibromatosis in childhood. F Pediatr 1970;76:339-46.

51 Dociu I, Galaction-Nitelea O, Şiriitã N, Murgu V. Centrofacial lentiginosis: a survey of 40 cases. $\mathrm{Br} \mathcal{F}$ Dermatol 1976;94:39-43.

52 Khairi MRA, Dexter RN, Burzynski NJ, Johnston CC Jr. Mucosal neuroma, pheochromocytoma and medullary thyroid carcinoma: multiple endocrine neoplasia type 3. Medicine (Baltimore) 1975; 54:89-112.

53 Voron DA, Hatfield HH, Kalkhoff RK. Multiple lentigines syndrome: case report and review of the literature. Am $\mathcal{F}$ Med 1976;60:447-56.

54 Scully RE. Sex cord tumor with annular tubules: a distinctive ovarian tumor of the Peutz-Jeghers syndrome. Cancer 1970;25:1107-21.

55 Albright F, Butler AM, Hampton AO, Smith P. Syndrome characterized by osteitis fibrosa disseminata, areas of pigmentation and endocrine dysfunction, with precocious puberty in females: report of five cases. N Engl $\mathcal{F}$ Med 1937;216:727-46.

56 Kissel P, Andre JM, Jacquier A. The neurocristopathies. New York: Masson Publishing, 1981.

57 Bolande RP. The neurocristopathies: a unifying concept of disease arising in neural crest maldevelopment. Hum Pathol 1974;5:409-29.

58 Harrison LH Jr, Said SI, Ezekowitz MD, Krous HF. Vasoactive intestinal polypeptide in cardiac myxoma. f Thorac Cardiovasc Surg 1985;89:800-6. 